\title{
Berantas Hoax Seputar Vaksin Covid-19 Melalui Kegiatan Edukasi dan Sosialisasi Vaksin Covid-19
}

\author{
Astri Nurdiana ${ }^{1}$, Rina Marlina $^{1}$, Weni Adityasning ${ }^{2}$ \\ ${ }^{1}$ Fakultas IImu Kesehatan, Universitas Singaperbangsa Karawang \\ ${ }^{2}$ Fakultas IImu Sosial dan Politik, Universitas Singaperbangsa Karawang \\ Email: astri.nurdiana@fikes.unsika.ac.id
}

\begin{abstract}
ABSTRAK
Ditengah merebaknya rencana pemerintah untuk pemberian vaksinasi Covid-19 (Sinovac) secara massal, berbagai hoax bermunculan di dalam media online, bahkan seringkali informasi tersebut disebarkan oleh akun-akun yang tidak memiliki kapasitas pengetahuan yang baik tentang vaksin Covid19. Berkembangnya hoax tersebut sangatlah membahayakan, salah satunya bagi bidan. Sebagai tenaga kesehatan bidan tidak dapat menghentikan pelayanannya selama pandemik Covid-19, karena masa kehamilan, persalinan, nifas dan bayi baru lahir merupakan masa yang tidak dapat dilakukan penundaan pelayanannya dalam kondisi apapun. Sebagai upaya mengkal permasalahan maka dilakukanlah sosialisasi dan edukasi seputar vaksin Covid-19 pada tanggal 18 Februari 2021 melalu media Zoom, Kegiatan tersebut melibatkan 209 peserta dan 2 narasumber, hasil kegiatan didapat peningkatan pengetahuan peserta seputar efikasi dan efektifitas vaksin Covid-19, serta ditemukannya perubahan sikap peserta tentang kesiapan diri untuk mendapatkan vaksinasi Covid-19 dari tidak mau dan ragu menjadi bersedia.
\end{abstract}

Kata kunci : Covid-19, Karawang, engetahuan, sikap, vaksin

\begin{abstract}
Amid the widespread government plans to give Covid-19 (Sinovac) vaccination en masse, various hoaxes have sprung up in online media, often this information is even spread by accounts that do not have good knowledge capacity about the Covid-19 vaccine. The development of hoaxes is very dangerous, one of which is for midwives. As a health worker, midwives cannot stop their services during the Covid-19 pandemic, because pregnancy, childbirth, post-partum and newborns are periods where services cannot be postponed under any circumstances. In an effort to address the problem, socialization and education were carried out about the Covid-19 vaccine on February 18, 2021 through Zoom media, this activity involved 209 participants and 2 resource persons, the results of the activity obtained an increase in participants' knowledge about the efficacy and effectiveness of the Covid-19 vaccine, and the discovery of changes. the attitude of participants about self-readiness to get Covid-19 vaccination from unwillingness and hesitation to being willing.
\end{abstract}

Keywords: Attitude, covid-19, Karawang, knowledge, pandemic, vaccine

\section{PENDAHULUAN}

Hingga bulan Februari 2021 tercatat sebanyak 113.543 .452 kasus Covid-19 di dunia (Worldometer, 2020). Lebih dari 7 juta spesimen telah diperiksa di seluruh Indonesia dan sebanyak 1.089.308 kasus diantaranya dinyatakan terkonfirmasi positif (Komite Penanganan Covid-19 dan Pemulihan Ekonomi Nasional, 2020). Pemerintah Indonesia mencatat 5 provinsi dengan kejadian Covid-19 tertinggi adalah DKI Jakarta, Jawa Barat, Jawa Tengah, Jawa Timur, Sulawesi Selatan dan Kalimantan Timur (Gugus Tugas Percepatan Penanganan Covid-19, 2020a). Temuan kasus Covid-19 di Karawang sebagai salah satu Kabupaten di Provinsi Jawa Barat hingga 15 Februari 2021 yaitu sebanyak 11.061 kasus terkonfirmasi, dengan peningkatan kasus harian mencapai 91 kasus. 1 tahun sudah bencana wabah Covid-19 terjadi, wabah yang dimulai dari Wuhan Cina hingga berlanjut ke berbagai penjuru dunia, termasuk Indonesia (Nurdiana, Wariah, \& Yanti, 2020; Shi et al., 2020; Zhai et al., 2020).

Berbagai tatanan kehidupan luluh lantah diterjang SARS-CoV2 virus penyebab Covid19 , pemerintah Indonesia telah melakukan beragam upaya untuk menghentikan penyebaran SARS-CoV2, salah satunya adalah kebijakan pembatasan sosial berskala besar (PSBB) yaitu 
dengan menutup jalur transportasi udara, darat dan laut, menghentikan sementara aktivitas pembelajaran serta bekerja secara tatap muka, menutup sementara sarana hiburan, saran ibadah serta sarana masyarakat lainnya (Gugus Tugas Percepatan Penanganan Covid-19, 2020b). Berbagai upaya dan strategi yang telah dilakukan tidak serta merata menghentikan penyebaran Covid-19 hingga kini, oleh karena itu pembentukan herd immunity (kekebalan masal) menjadi alternatif terakhir yang dapat dilakukan untuk mencegah penularan covid-19 (Lytras \& Tsiodras, 2021), namun pembentukan herd immunity secara natural dengan penularan Covid-19 yang kini terjadi tidak akan berjalan cepat dibandingkan dengan pemberian imunisasi secara masal melalui vaksinasi (Lytras \& Tsiodras, 2021).

Ditengah merebaknya rencana pemerintah untuk pemberian vaksinasi Covid-19 (Sinovac) secara massal, berbagai hoax bermunculan di dalam media online, bahkan seringkali informasi tersebut disebarkan oleh akun-akun yang tidak memiliki kapasitas pengetahuan yang baik tentang vaksin Covid-19 (Hoax Buster, 2021). Berkembangnya hoax tersebut sangatlah membahayakan, salah satunya bagi bidan. Sebagai tenaga kesehatan bidan tidak dapat menghentikan pelayanannya selama pandemik Covid-19, karena masa kehamilan, persalinan, nifas dan bayi baru lahir merupakan masa yang tidak dapat dilakukan penundaan pelayanannya dalam kondisi apapun (Renfrew et al., 2020; Richens, Wilkinson, \& Connor, 2020). Sebagai upaya mengkal permasalahan tersebut upaya sosialisasi dan edukasi seputar vaksin Covid-19 perlu dilaksanakan, terutama bagi tenaga Kesehatan sebagai orang yang berperan dalam memberikan informasi bagi masyarakat.

\section{BAHAN DAN METODE}

Pelaksanaan kegiatan pengabdian pada masyarakat ini dilakukan di Kabupaten Karawang melalui kegiatan webinar, kegiatan webinar ini bekerjasama dengan Ikatan Bidan Indonesia sebagai mitra, sasaran kegiatan adalah profesi bidan di Kabupaten Karawang, dipilihnya bidan sebagai sasaran karena selama kondisi pandemik pelayanan kebidanan merupakan jenis pelayanan yang tidak dapat dihentikan sementara, selain itu selama pandemik pemerintah melibatkan bidan sebagai tenaga kesehatan yang menangani Covid-19 di masyarakat. Adapun Langkah pelaksanaan kegiatan pengabdian kepada masyarakat yang telah dilakukan sebagaimana langkah-langkah pada gambar 1.

Kegiatan dimulai dengan analisis situasi dari permasalahan yang dihadapi oleh mitra, setelah ditemukannya masalah dilakukan penandatanganan kesepatakatan dengan mitra untuk menyelesaikan masalah, setelah ditemukan metode penyelesaikan masalah yang akan dilakukan melalui kegiatan webinar, maka dilanjutkan dengan pembentukan panitia dan pemilihan narasumber kegiatan.

Narasumber webinar yang dipilih adalah Dr. Hasta Handayani Idrus, M.Kes selaku pakar dalam bidang mikrobiologi dan Bd. Eneng Solihah, S.SiT, M.Keb selaku pengurus cabang Ikatan Bidan Indonesia Kabupaten Karawang. Webinar dilaksanakan pada hari Kamis, 18 Februari 2021 Pukul 08.30-11.30, melalui Zoom. Metode pelaksanaan webinar dilakukan dengan cara diskusi interaktif antara narasumber dan peserta kegiatan, sebelum dimulai kegiatan peserta diminta untuk mengisi terlebih dahulu kuesioner pre-test yang berisi tentang data demografi, pengalaman vaksinasi Covid-19 serta pengetahuan seputar vaksin Covid-19, kemudian dilanjutkan dengan pemberian materi, lalu diakhiri dengan pengisian post-test.

\section{HASIL}

Kegiatan webinar ini telah berhasil dilaksanakan pada tanggal 18 Februari 2021, dengan dihadiri oleh sebanyak 209 peserta yang tersebar di Provinsi Jawa Barat (tabel 1). Berdasarkan tabel 1 diketaui bahwa mayoritas peserta kegiatan adalah mahasiswa, dan mayoritas peserta berasal dari perguruan tinggi negeri ataupun swasta, mayoritas usia peserta adalah antara 2040 tahun, selain itu berdasarkan data tersebut di atas diketahui pula bahwa mayoritas peserta belum mendapatkan vaksinasi Covid-19.

Evaluasi peserta pada kegiatan edukasi dan sosialisasi vaksin Covid-19 dilakukan dengan metode pre dan post-tes, peserta diminta untuk mengisi kuesioner sederhana yang 
mengukur pengetahuan dan sikap. Pertanyaan pengetahuan berisi 3 pertanyaan yang berisi tentang definisi, efikasi dan efektifitas vaksin Covid-19. Pertanyaan sikap berisi 1 pertanyaan yang ditanyakan hanya pada peserta yang belum diberikan vaksinasi covid-19. Hasil evaluasi peserta tercantum dalam tabel 2 .

Tabel 2 menunjukan bahwa berdasarkan hasil pre dan post-test diketahui bahwa pengetahuan peserta tentang efikasi vaksin dan efektifitas vaksin meningkat setelah dilakukan edukasi mengenai vaksin Covid-19, namun peserta belum dapat memahami secara benar tentang definisi vaksinasi.

Tabel 3 merupakan tabel pengukuran sikap antara sebelum dan sesudah pemberian edukasi dan sosialisasi vaksin Covid-19, dengan menanyakan kesediaan peserta yang belum pernah melakukan vaksinasi Covid-19 sebanyak 165 peserta tentang kesediaannya untuk mendapatkan vaksinasi. Hasil kajian menunjukan bahwa terdapat perubahan sikap peserta kegiatan antara sebelum dan sesudah pemberian edukasi dan sosialisasi Vaksin Covid-19, hal itu terlihat dari jumlah peserta yang tidak ingin dan ragu untuk mendapatkan vaksinasi Covid19 terjadi penurunan, sehingga jumlah peserta yang ingin mendapatkan vaksinasipun meningkat sebesar $3,1 \%$.

\section{PEMBAHASAN}

Wacana pencegahan penyebaran Covid-19 melalui vaksinasi telah bergulir sejak terjadinya wabah di penghujung 2019 , hingga penyebaran wabah tersebut secara massif ke berbagai negara di dunia, Pagliusi et al. (2020) dalam artikelnya yang berjudul "Emerging manufacturers engagements in the COVID -19 vaccine research, development and supply" menjelaskan vaksinasi Covid-19 telah melalui berbagai tahapan uji coba yang dilakukan di berbagai tempat, seperti di Beijing Institute of Biological Products, Bharat di India, Eubiologics di Korea, Biomanguinhos/Fundaçāo Oswaldo Cruz and Instituto di Buntantan Brazil, Serum Institute di India, Sinovac di Cina, Sydus Cadila di India, Minhai Biotechnology di China, BioNetAsia di Thailand, Crovovax di Cina, Indian Immunologicals di India, Innovax di Cina, dan tempat lainnya Taiwan, Rusia dan Vietnam. Uji coba dilakukan melalui tahap fase 1 dan 2 hingga tahap pre-klinik (Pagliusi et al., 2020). Namun, keberadaan program vaksinasi Covid-19 memunculkan beberapa pertanyaan yang bersumber dari pasien, terutama ketika pasien memiliki penyakit penyerta yang belum teukur secara akurat efek yang mungkin timbul jika dilakukan vaksinasi (Živković et al., 2021). Wibawa (2021) menyebutkan setidaknya terdapat 5 tantangan yang dihadapi selama proses invensi vaksin Covid-19 yaitu: [1] kurangnya pemahaman tentang patogenesis dan peran prediktif vaksin dalam jalur klinis orang yang terinfeksi oleh SARS-CoV-2 [5-7], [2] ketidaksepakatan di antara para ahli tentang bagaimana menentukan epitop yang paling imunogenik dan antigen SARS-CoV2, [3] temuan bahwa peningkatan ketergantungan antibodi dapat berkontribusi pada penyakit SARS-CoV2 yang berlebihan, [4] model hewan yang mapan untuk uji vaksin COVID-19 yang terbatas, [5] spekulasi tentang durasi proteksi. Selain itu Wibawa (2021) menyebutkan pemberian vaksin pada manusia harus memenuhi persyaratan keamanan (safety), efektifitas (efficacy) dan kualitas (quality) (Wibawa, 2021).

Meskipun terapi Covid-19 dengan menggunakan plasma covalesent dari penderita Covid-19 telah membuahkan hasil yang positif, namun penggunaan vaksinasi Covid-19 tetap menjadi tindakan yang sangat diperlukan, karena vaksinasi Covid-19 diperlukan untuk merangsang respon antibodi dalam tubuh sehingga dapat memberikan perlindungan jangka panjang (Lv, Wu, \& Mok, 2020).

Eibich \& Goldzahl, (2020) dalam kajiannya tentang pengetahuan seseorang tentang informasi Kesehatan meyebutkan bahwa, keterpaparan seseorang tentang informasi Kesehatan dapat mempengaruhi pengetahuannya, sedangkan pengetahuan seseorang tidak terlalu berdampak terhadap perubahan perilaku, akan tetapi praktik perilaku pencegahan banyak dipengaruhi oleh faktor lainnya seperti keyakinan tentang efektifitas dari metode pencegahan untuk mencegah timbulnya penyakit, serta persepsi seseorang tentang resiko 
yang mungkin muncul (Eibich \& Goldzahl, 2020). Sejalan dengan penelitian Lee, Kang, \& You, (2021) yang menyebutkan bahwa pengetahuan secara langsung dapat berhubungan dengan sikap seseorang dan perilaku pencegahan penyakit yang dilakukannya, namun keyakinan seseorang tentang efikasi dari suatu metode pencegahan menjadi faktor yang paling berpengaruh jika dibandingkan dengan faktor pengetahuan (Lee et al., 2021).

Sulistyawati et al. (2021) melakukan studi di Indonesia untuk mengukur pengetahuan sikap, praktik dan kebutuhan informasi selama masa pandemik di Indonesia, studi tersebut dilakukan dengan melibatkan 816 responden dari seluruh Indonesia, hasil studi tersebut menyebutkan bahwa pengetahuan seseorang tentang Covid-19 dapat dipengaruhi oleh usia, pendidikan, serta jenis pekerjaan. Responden yang berumur $>30$ tahun memiliki pengetahuan yang lebih baik dibandingkan dengn responden berumur $<30$ tahun, selain itu semakin tinggi Pendidikan seseorang maka semakin baik pula pengetahuannya tentang Covid-19 (Sulistyawati et al., 2021).

\section{KESIMPULAN DAN SARAN}

Kegiatan pengabdian kepada masyarakat ini telah dilaksanakan pada tanggal 18 Februari 2021 melalui media Zoom dan dihadiri oleh sebanyak 209 peserta, kegiatan dilakukan dengan metode pre dan post-test menggunakan kuesioner sebagai alat ukur pengetahuan dan sikap peserta kegiatan yang berkaitan dengan vaksin Covid-19. Hasil evaluasi pengetahuan didapatkan peningkatan pengetahuan responden tentang efikasi dan efektifitas vaksin sesudah dilakukannya edukasi dan sosialisasi tentang vaksin Covid-19. Selain itu jumlah responden yang bersedia untuk mendapatkan vaksin Covid-19 lebih tinggi sesudah kegiatan dibanding dengan sebelum kegiatan.

\section{UCAPAN TERIMA KASIH}

Pelaksana kegiatan mengucapkan terima kasih kepada Universitas Singaperbangsa Karawang, Fakultas IImu Kesehatan Unsika dan Pengurus Cabang Ikatan Bidan Indonesia Kabupaten Karawang yang telah memberikan dukungan materil maupun immaterial bagi terselenggaranya kegiatan ini.

\section{DAFTAR PUSTAKA}

Eibich, P., \& Goldzahl, L. (2020). Health information provision, health knowledge and health behaviours: Evidence from breast cancer screening. Social Science and Medicine, 265(November). https://doi.org/10.1016/j.socscimed.2020.113505

Gugus Tugas Percepatan Penanganan Covid-19. (2020a). Infografis Covid-19 di Indonesia. Jakarta.

Gugus Tugas Percepatan Penanganan Covid-19. (2020b). Pedoman Penanganan Cepat Medis dan Kesehatn Masyarakat Covid-19 di Indonesia. Gugus tugas percepatan penanganan covid-19. Jakarta: Kementerian Kesehatan Republik Indonesia.

Hoax Buster. (2021). [SALAH] "Vaksin Sinovac Covid-19 yang akan di suntikkan kepada warga hanya untuk kelinci percobaan." Retrieved January 12, 2021, from https://covid19.go.id/p/hoax-buster/salah-vaksin-sinovac-covid-19-yang-akan-disuntikkan-kepada-warga-hanya-untuk-kelinci-percobaan

Komite Penanganan Covid-19 dan Pemulihan Ekonomi Nasional. (2020). Peta Sebaran Covid19 di Indonesia. Retrieved December 12, 2020, from https://covid19.go.id/peta-sebaran

Lee, M., Kang, B. A., \& You, M. (2021). Knowledge, attitudes, and practices (KAP) toward COVID-19: a cross-sectional study in South Korea. BMC Public Health. https://doi.org/10.1186/s12889-021-10285-y

Lv, H., Wu, N. C., \& Mok, C. K. P. (2020). COVID-19 vaccines: Knowing the unknown. European Journal of Immunology, 50(7), 939-943. https://doi.org/10.1002/eji.202048663

Lytras, T., \& Tsiodras, S. (2021). Lockdowns and the COVID-19 pandemic: What is the endgame? Scandinavian Journal of Public Health, 49(1), 37-40. 
https://doi.org/10.1177/1403494820961293

Nurdiana, A., Wariah, U., \& Yanti, I. (2020). Double Threat of Indonesian Maternal Health During The Pandemic of Covid-19. Jurnal IImu Dan Teknologi Kesehatan, 8(1), 64-79. https://doi.org/10.32668/jitek.v8i1.429

Pagliusi, S., Jarrett, S., Hayman, B., Kreysa, U., Prasad, S. D., Reers, M., Desai, S. (2020). Emerging manufacturers engagements in the COVID -19 vaccine research, development and supply. Vaccine. https://doi.org/10.1016/j.vaccine.2020.06.022

Renfrew, M. J., Cheyne, H., Craig, J., Duff, E., Dykes, F., Hunter, B., ... Downe, S. (2020). Sustaining quality midwifery care in a pandemic and beyond. Midwifery. https://doi.org/10.1016/j.midw.2020.102759

Richens, Y., Wilkinson, M., \& Connor, D. (2020). Guidance for the provision of antenatal services during the COVID-19 pandemic. British Journal of Midwifery, 28(5), 324-327. https://doi.org/10.12968/bjom.2020.28.5.324

Shi, Y., Wang, G., Cai, X., Deng, J., Zheng, L., Zhu, H., ... Chen, Z. (2020). An overview of COVID-19, 1581, 1-18.

Sulistyawati, S., Rokhmayanti, R., Aji, B., Wijayanti, S. P. M., Hastuti, S. K. W., Sukesi, T. W., \& Mulasari, S. A. (2021). Knowledge, attitudes, practices and information needs during the covid-19 pandemic in indonesia. Risk Management and Healthcare Policy, 14, 163-175. https://doi.org/10.2147/RMHP.S288579

Wibawa, T. (2021). COVID-19 vaccine research and development: ethical issues. Tropical Medicine and International Health. https://doi.org/10.1111/tmi.13503

Worldometer. (2020). Reported Cases and Deaths by Country, Territory, or Conveyance. Retrieved from https://www.worldometers.info/coronavirus/\#countries

Zhai, P., Ding, Y., Wu, X., Long, J., Zhong, Y., \& Li, Y. (2020). The epidemiology , diagnosis and treatment of COVID-19. International Journal of Antimicrobial Agents, 55.

Živković, S. A., Gruener, G., Narayanaswami, P., Arnold, M. L., Del Toro, D. R., Desai, U. G., Venesy, D. A. (2021). Doctor-Should I get the COVID-19 vaccine? Infection and immunization in individuals with neuromuscular disorders. Muscle and Nerve. https://doi.org/10.1002/mus.27179 


\section{LAMPIRAN}

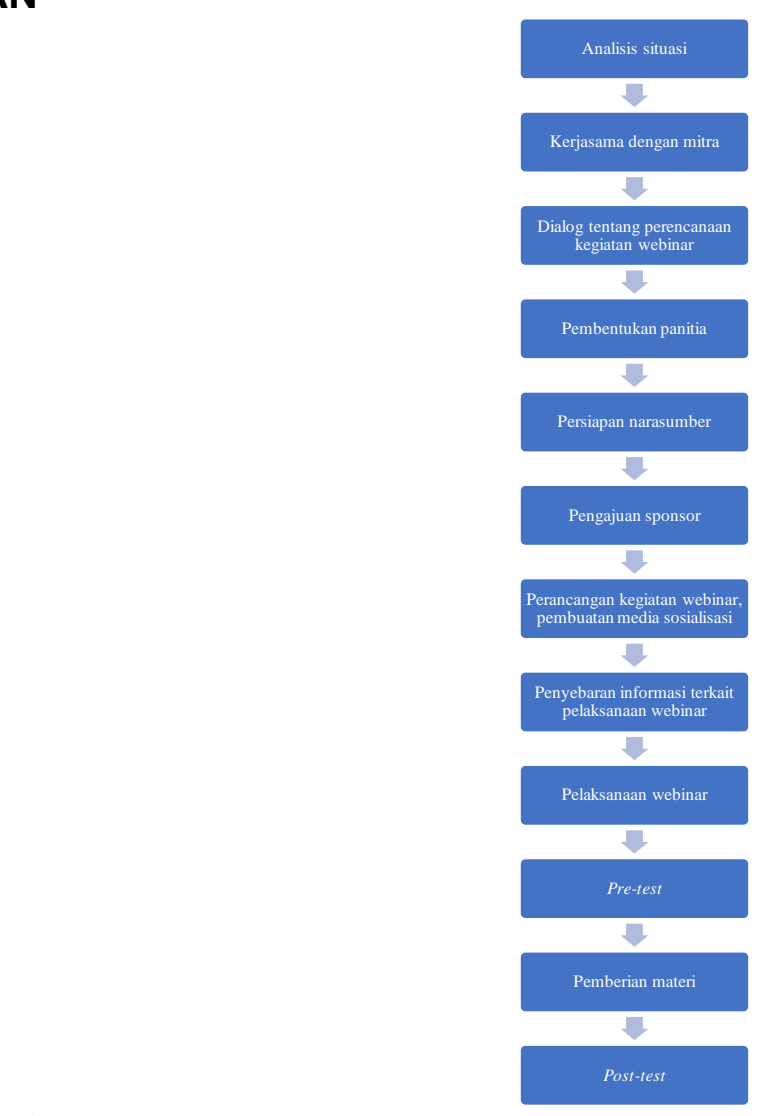

Gambar 1. Alur Pelaksanaan Kegiatan Pengabdian Pada Masyarakat

Tabel 1. Data Peserta Kegiatan Edukasi

\begin{tabular}{lc}
\hline \multicolumn{1}{c}{ Kategori } & Jumlah $(\mathrm{n}=209)$ \\
\hline Pekerjaan & \\
Bidan & $44 \%$ (92 Orang) \\
Mahasiswa & $55 \%(115$ Orang) \\
Lain-lain & $1 \%(2$ Orang) \\
Asal Institusi & \\
Praktik Mandiri Bidan & $8,1 \%(17$ Orang) \\
PTN/PTS & $52,6 \%(110$ Orang) \\
Puskesmas & $11,5 \%(24$ Orang) \\
Klinik & $8,6 \%(18$ Orang) \\
Rumah Sakit & $7,7 \%(16$ Orang) \\
Lain-lain & $11,5 \%(24$ Orang) \\
Usia Peserta & \\
$\quad<20$ tahun & $27,3 \%(57$ Orang) \\
20-40 tahun & $60,8 \%(127$ Orang) \\
>40 tahun & $12,0 \%(25$ Orang) \\
Mendapatkan Vaksin & \\
Sudah & $21,1 \%(44$ Orang) \\
Belum & $78,9 \%(165$ Orang) \\
\hline
\end{tabular}

Tabel 2. Hasil Pre dan Post-Test Pengetahuan

\begin{tabular}{llll}
\hline Pertanyaan/Pernyataan & Pre & Post & Keterangan \\
\hline Vaksinasi adalah...... & & &
\end{tabular}




\begin{tabular}{|c|c|c|c|}
\hline Jawaban Benar & $\begin{array}{c}81,8 \%(171 \\
\text { Orang) }\end{array}$ & $\begin{array}{c}69,4 \%(145 \\
\text { Orang) }\end{array}$ & Menurun \\
\hline Jawaban Salah & $\begin{array}{c}\text { 18,2\%(38 } \\
\text { Orang) }\end{array}$ & $\begin{array}{c}30,6 \%(64 \\
\text { Orang) }\end{array}$ & Meningkat \\
\hline \multicolumn{4}{|c|}{$\begin{array}{l}\text { Dibandingkan dengan } \\
\text { Sinovac Turki dan } \\
\text { Brasil, vaksin Sinovac } \\
\text { Indonesia memiliki } \\
\text { efikasi tertinggi }\end{array}$} \\
\hline Jawaban Benar & $\begin{array}{c}37,3 \%(78 \\
\text { Orang) }\end{array}$ & $\begin{array}{c}42,6 \%(89 \\
\text { Orang) }\end{array}$ & Meningkat \\
\hline Jawaban Salah & $\begin{array}{c}62,7 \%(131 \\
\text { Orang) }\end{array}$ & $\begin{array}{c}57,4 \%(120 \\
\text { Orang) }\end{array}$ & Menurun \\
\hline \multicolumn{4}{|l|}{$\begin{array}{l}\text { Vaksinasi Covid tetap } \\
\text { efektif walaupun } \\
\text { dilakukan hanya } 1 \text { kali }\end{array}$} \\
\hline Jawaban Benar & $\begin{array}{c}37,3 \%(78 \\
\text { orang) }\end{array}$ & $\begin{array}{c}80,9 \%(169 \\
\text { Orang) }\end{array}$ & Meninggkat \\
\hline Jawaban Salah & $\begin{array}{c}62,7 \%(131 \\
\text { orang) }\end{array}$ & $\begin{array}{c}\text { 19,1\% (40 } \\
\text { Orang) }\end{array}$ & Menurun \\
\hline
\end{tabular}

Tabel 3. Hasil Pre dan Post-Test Sikap

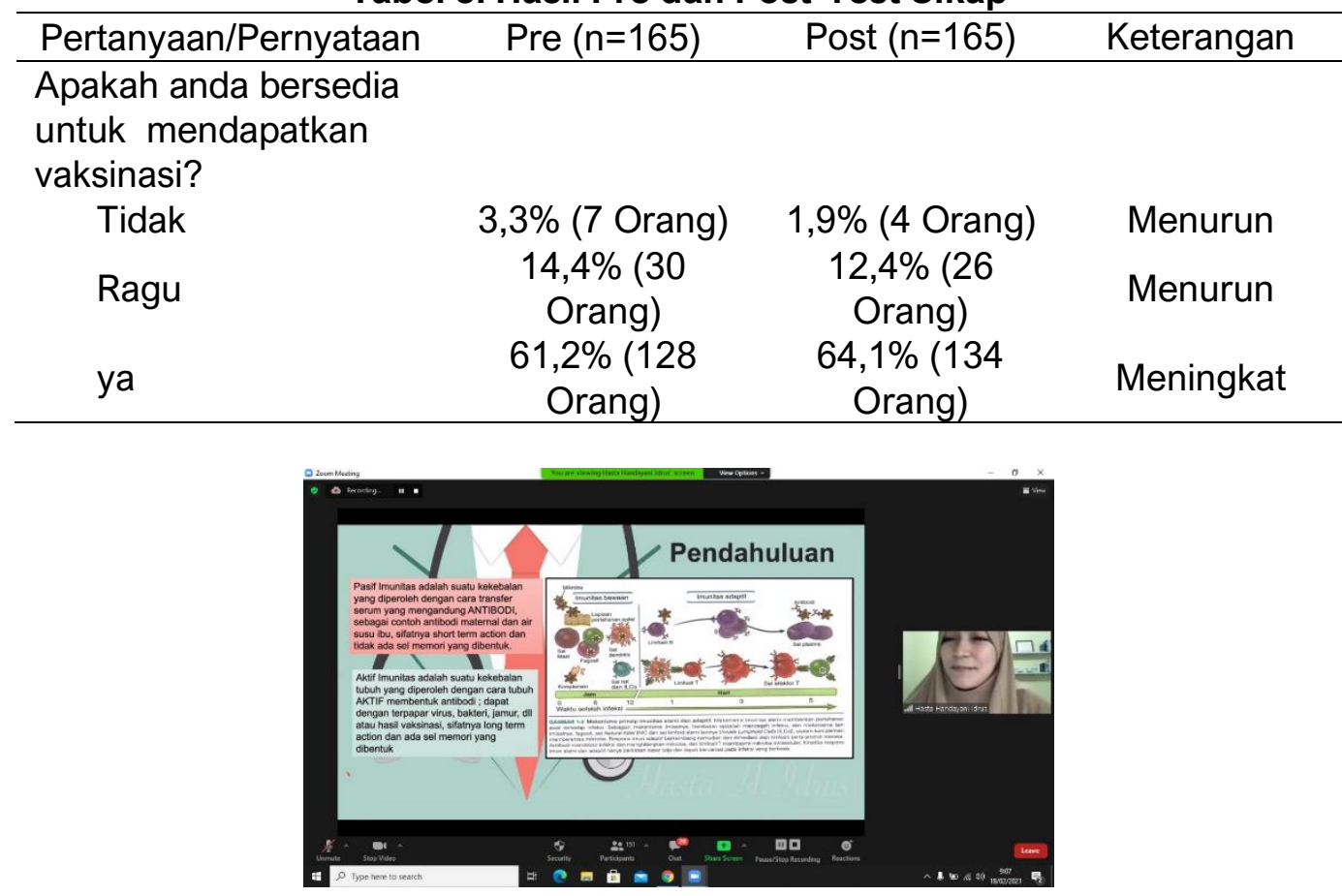

Gambar 2. Kegiatan Edukasi dan Sosialisasi Vaksin Covid-19 